\title{
Revealing the Legal Protection of Patients Social Security Administration Agency of Health in Sanglah and Balimed Hospitals Denpasar
}

\author{
RA Tuty Kuswardhani and I Nyoman Budiana \\ Magister of Law, Undiknas University, Denpasar \\ tutykuswardhani@yahoo.com, budiananyoman1961@gmail.com
}

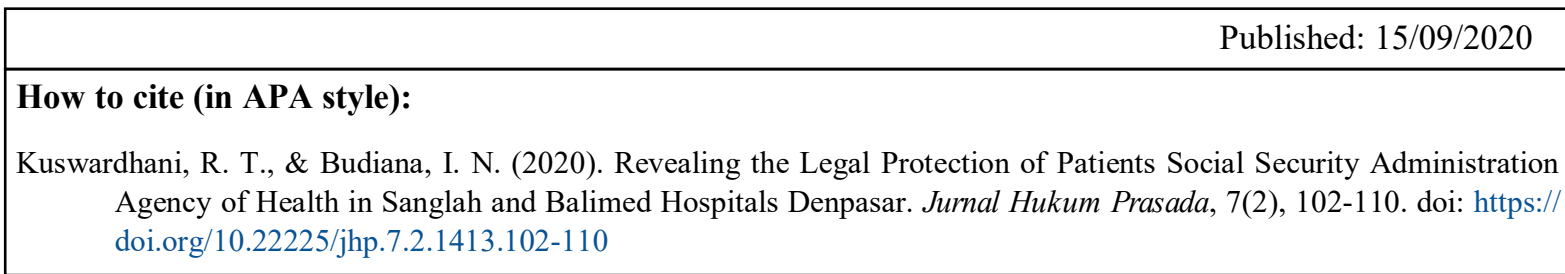

\begin{abstract}
Social Security Administration Agency of Health has a National National Health Insurance formulary, but in reality patients do not get drugs according to the National Health Insurance National Formulary. Therefore, the aims of this study are to determine the legal protection of patients of the Social Security Administration Agency of Health for the elderly in curative therapy in hospitals according to the national formulary of National Health Insurance at Sanglah Hospital and Balimed Hospital, and to know the responsibilities undertaken by the Social Security Administration Agency of Health in fulfilling its obligations for patients the Agency for the Implementation of the Social Health Insurance of the elderly in curative therapy in accordance with the national formulary of the National Health Insurance. This study uses a participatory observational (empirical-observational) empirical legal research method. Sampling with purposive sampling and data collection techniques using triangulation techniques. In principle, legal protection must refer to legal certainty, fairness and benefits for the population participating in the Social Security Administration Agency of Health for the elderly so that it is not impressed that Balimed Hospital and Sanglah General Hospital and the Social Security Administration Agency of Health make a service to consumers who are not good. The legal responsibility that should be obtained by the participants of the Social Security Administration Agency of Health for the elderly in Balimed Hospital and Sanglah Hospital Denpasar which is currently not maximally received by patients participating in the Social Security Administration Agency of Health for the elderly at Balimed Hospital and Sanglah Hospital.
\end{abstract}

Keyword: Legal Protection; Legal Responsibility; Elderly; Social Security Administration Agency of Health.

\section{INTRODUCTION}

The main priority that must be implemented by the hospital is patient safety, because it can provide protection to patients from unexpected events. This incident can occur when health workers provide health services to patients through health programs in hospitals. This is very closely related to the quality of hospital services.

Republic of Indonesia 1945 Constitution Article $28 \mathrm{H}$, stipulates that health is a fundamental right of every citizen, therefore, families and communities have the right to receive protection for their health and the state is responsible for regulating the fulfillment of the right to healthy living for its residents as well as Law No. 36/2009 which states about health. World Health Organization (WHO) has determined that health is an investment, rights and obligations for every human being. The quote is also contained in Article 28 paragraph (3) of the 1945 Constitution of the Republic of Indonesia, hereinafter abbreviated as (1945 Constitution of the Republic of Indonesia) and the Health Act hereinafter 
abbreviated as (UUK) which stipulates that everyone has the right to receive health services. Every individual, family and community has the right to receive protection for their health, and the state is responsible for regulating the fulfillment of the right to live healthy for its population, including for the poor and disadvantaged.

Professional curative services are based on competencies that are appropriate to certain expertise and skills in the medical field. The service is provided in the form of providing assistance or assistance based on patient confidence in the doctor. Health services performed by doctors to patients must be supported with adequate infrastructure or in other words the facilities that support these facilities can help doctors in providing health services to patients including curative therapy examinations in elderly patients according to the national formulary (Fronas) National Health Insurance (Siregar \& Budhiartie, 2013).

Participants of the Social Security Administration Agency of Health have the right to get health services in the form of health social security benefits in hospitals while hospitals are required to serve them (Peraturan BPJS Kesehatan, 2014). Patients from the Social Security Administration Agency of Health are consumers of health service users. As users of health services, patients are also referred to as consumers so that in this case also applies the provisions of Law No. 8 of 1999 concerning Consumer Protection (UndangUndang No 8, 1999).

Participants in the Social Security Administration Agency of Health consist of various young age to old age. The elderly group is one of the Social Security Administration Agency of Health participants who has a big part in their participation in Indonesia. Referring to the Republic of Indonesia Act of 1998 and WHO 2005 for developing countries in Indonesia, a person is grouped into the elderly if they are 60 years old. WHO classify the elderly into 3 stages, namely: elderly, old and oldest. Seniors, every elderly has the right to live and survive; get fulfillment of basic needs; justice and legal protection; health services; civic participation; religious and spiritual; use public facilities for elderly activities including sports; culture and tourism; social welfare; accessibility; public service; get protection from exploitation, violence, and mistreatment both inside and outside the home; disaster protection and management; involved in the community; basic administrative and population services; and get a job.

Elderly Regional Regulation No. 11 Bali is regulated in a Bali Governor Decree in 2018 , whose role is to regulate and guarantee the welfare of the elderly, one of which is to improve health services for the elderly. Provincial/Regency/City/Private Government Hospital, public health service, clinic, main clinic are required to provide elderly (Geriatric) health care services and/or are elderly-friendly. This Geriatric and /or elderly-friendly service is intended for the development of healthy living behaviors, prevention of health problems, treatment services and rehabilitation of elderly health so that their physical, mental, spiritual and social conditions are functioning optimally (Susamto, 2011).

The hospital in giving patient rights also must always maintain patient safety in accordance with standard patient safety procedures. If the patient does not get his rights due to negligence or inadvertence of health workers causing harm to the patient, the hospital must be legally responsible (Anonim, 2017).

Hospital pharmacy services are one of the activities of hospitals that support quality health services. Patient and community demands for pharmaceutical services to be ideal require a change of service from the old paradigm to the new paradigm. Pharmacy service practice is an integrated activity with the aim of identifying, preventing and resolving drug problems and health-related problems related to individual health (Peraturan Menteri Kesehatan Republik Indonesia, 2015).

Drugs that are not available in hospitals or health facilities for curative therapy in elderly patients, greatly affect the morbidity and even mortality rates of the elderly population. Some drugs that are needed by the elderly population such as drugs for nausea and vomiting therapy, cough medicines, anti-hypertensive drugs, diabetes drugs, antibiotic drugs in national formulary of national health insurance are very priority for curative therapy in the elderly population. If it is not available and even a replacement is not available, it will 
affect the health of the individual. That it is very different physical conditions in young people and older people in terms of the outcome of curative therapy (Peraturan Menteri Kesehatan, 2007).

In the elderly population it is more dangerous to have an effect on the old body if the medicine is not according to the doctor's indication, because it can be fatal. So that the elderly group does not arbitrarily replace drugs or give inappropriate drugs. It is interesting to conduct in-depth research on secondary and tertiary health facilities (Kemenkes-RI, 2014).

National Health Insurance, making a national formulary that contains drug items that are available nationally, so prescriptions given to patients must refer to national formulary of national health insurance. Elderly Social Security Administration Agency Patients who in practice turned out to have not received a prescription according to the national formulary of national health insurance. Participants of the Social Security Administration Agency of Health are suspected to be many who were told to buy drugs and blood transfusions that actually had been included in the Social Security Administration Agency of Health package (Anonim, 2016).

The results of an interim survey in the City of Clean Banten revealed the fact, there are still patients who use the Social Security Administration Agency of Health services who must buy their own medicines after using a national health insurance card at a health facility in Serang City, Banten.

Many Social Security Administration Agency of Health patients do not get drugs from hospital pharmacy because of the reasons from the pharmacy the availability of drugs prescribed by doctors is empty. Normatively the Social Security Administration Agency of Health has a national formulary of national health insurance but in reality patients do not get drugs according to the national formulary of national health insurance. Sanglah Hospital Denpasar as a referral center hospital in Bali, as a tertiary health facility in Bali found similar things in the Bali area is the Balimed Hospital which has been nationally accredited Plenary Hospital in 2019 , as a secondary health facility, this hospital that was established in 2008 has a specialist consultant doctor complete one of the leading hospitals is Geriatri (Elderly Health) service with a mission: providing patient services for all elements of the hospital and customer satisfaction oriented (Republika, 2018).

Some research about legal protection of the Social Security Administration Agency of Health have been conducted such as Yudiana, Listyaningrum, \& Dwi (2020) stated that Legal protection for patients using the Health social security administering Agency at Mataram City Hospital has protected their rights as service consumers, as hospital patients or as participants of the Health social security administering Agency as regulated in the National Social Security System Law and Health Law. Suhartoyo (2018) conveyed that the implementation of BPJS Health program at Bhayangkara Indramayu Hospital has been running quite well in accordance with Presidential Regulation No. 12 of 2013 on health insurance. Danandhika, Putrawan, \& Bagiastra (2016) said that the rights of underprivileged patients who participate in BPJS Kesehatan at RSU Puri Raharja are considered not optimal in terms of health services when seen in cases of childbirth that are rejected by the hospital.

Based on the above problem, researchers are interested to conduct this research to determine the legal protection of patients of the Social Security Administration Agency of Health for the elderly in curative therapy in hospitals according to the national formulary of National Health Insurance at Sanglah Hospital and Balimed Hospital, and to know the responsibilities undertaken by the Social Security Administration Agency of Health in fulfilling its obligations for patients the Agency for the Implementation of the Social Health Insurance of the elderly in curative therapy in accordance with the national formulary of the National Health Insurance

\section{METHOD}

This research will be carried out in the Geriatri and the Flamboyan Inpatient Room at Sanglah Hospital (tertiary health facilities) as well as in the Polyclinic and inpatient rooms of 
the Denpasar Balimed Hospital (secondary health facilities). This research uses a participatory observational (empirical-observational) legal juridical legal research method which is a type of sociological legal research and with field research that examines the applicable legal provisions and what happens in reality in the community, observed by researchers involved and participate in.

Sampling with purposive sampling that is one of the non-random sampling techniques where the researcher determines the sampling by determining specific characteristics in accordance with the objectives of the study so that it is expected to answer the research problem. Data collection techniques using triangulation techniques (Denkin, 2013).

Respondents in this study were: 1). patients of the Senior Health Insurance Provider Agency accompanied by their care giver in the two hospitals that have been stated previously, 2). (Patient Responsible Doctor), 3). As Informants: pharmaceutical officials in Sanglah Hospital and Balimed Hospital Denpasar 4). as well as Social Security Administration Agency of Health officials who occupy certain positions responsible for the implementation of health services in both hospitals in Denpasar.

\section{RESULT AND DISCUSSION}

The total number of respondents in this study were 37 respondents consisting of 10 Balimed Hospital patients, 10 Sanglah Hospital patients, 4 Balimed Hospital doctors, 7 Sanglah Hospital doctors, 3 Balimed Hospital Officials, 2 Sanglah Hospital Officials and 1 Official of the Social Dept. Bali, NTT and NTB.

From the analysis of Balimed Hospital patients: some were replaced with other types of insulin that were not as indicated. Some get drugs but they arrive more than 7 days late (laksadin drugs and cough medicines) so that it disrupts the patient's condition. Besides that, there are drugs that are empty for 1 month (anti-fat drugs). Meanwhile, antibiotic drugs that are appropriate indications for elderly patient diseases remain empty replaced with drugs whose level is lower than the drugs that are indicated earlier so that patients do not recover from the infection.

Insulin medicine remains empty already looking around the pharmacy was informed so by the nurse. The medicine is not given / replaced, the medicine remains empty. Cannot be Insulin because you are told to look for at the Social Security Administration Agency's Pharmacy outside the hospital and at the pharmacy the medicine is empty. As is known to all curative therapies in this case drug therapy to elderly citizens always have side effects if it is not an exact indication. For example, as shown below:

insulin, a person with diabetes mellitus if high blood sugar levels let alone accompanied by any infection; also suffer from coronary heart disease, such as patients above $700 \mathrm{mg} / \mathrm{dL}$ should have been given insulin therapy, but the Social Security Administration Agency made a circular to the Deputy Directors of the Regional Social Security Administration Agency of Health throughout Indonesia dated March 15, 2019 as follows:

In connection with guaranteeing the use of Parenteral Antidiabetic drugs for National Health Insurance Participants, herewith delivered the following matters:

1. In accordance with the letter of the Director General of Pharmaceuticals and Medical Devices of the Ministry of Health Number FY.03.01 / III / 337/2019 concerning Explanations of Restrictions on the Use of Insulin, it is conveyed that: Changes to the intended restriction as listed in Sub-Class Therapy 16.2.2 Parenteral Antidiabetes is

a. That the restriction is intended for new patients using insulin, namely patients with type 2 diabetes mellitus who have never received insulin therapy.

b. Insulin law (intermediate acting, insulin mix) or insulin analog (mix, long acting insulin) can be given to patients with type 2 diabetes mellitus:

c. That is not controlled by the administration of a combination of optimal dose metformin and other oral diabetes drugs. 
d. The content $\mathrm{HbA} 1 \mathrm{C}>9 \%$.

e. This restriction does not apply to patients with type 1 diabetes mellitus or who have previously used insulin.

2. Refer to point 1 , limits and criteria for insulin users:

a. The definition of optimal dose metformin is the administration of metformin in doses according to the 's infiltration which has taken into account the conditions of each participant and the maximum absorption of Fornas.

b. As a medication monitoring and in the context of educating the lifestyle arrangement of National Health Insurance Participants with Type II DM, HbA1C examination can be done every 6 months in primary health care / network laboratory / collaborating laboratory / secondary health facilities.

c. In the case of the use of insulin drug as a chronic drug for chronic diseases in secondary health facilities in the case of RJTL, the Veificator must verify the amount of penfill / cartridge / vial needed according to the insulin dose first. Furthermore insulin drug financing follows the pattern of drug financing for chronic diseases in secondary health facilities in general, viz:

1) The cost of using penfill / cartridge / vial for needs of at least 7 days is included in the INA CBG package;

2) The cost of using penfill / cartridge / vial for as much as 23 days needs can be billed separately outside the INA CBG package (Ina CBGs, 2017).

Participants in the Social Security Administration Agency of Health were not given an explanation as described above. Moreover, $\mathrm{HbA1C}$ laboratory examinations must be paid for by patients not by the ocial Security Administration Agency of Health, whereas in the Minister of Health regulation in INA CBG it has been stated that all costs of generic drug therapy and laboratories are borne by the social Security Administration Agency of Health.

From the analysis of interviews with doctors from Sanglah Hospital, the alternative was trying to administer medicine but still did not get the medicine. Replaced with drugs that are lower in class, patients must be able to get the medicine and be replaced with other drugs that are not very precise indications. Always try to be there, if there is no search and no later than 7 days it must be held even if it is replaced by a branded drug but with the same price as a generic buying drugs with a hospital bailout still cannot get medicine and is constrained by purchasing too expensive because of the small amount. doctors hope that the Social Security Administration Agency of Health system can be better for the benefit of patients, medical staff, hospitals, the State. The doctor's hope besides that is that the Social Security Administration Agency should continue to try to replace the vacancy of the drug by using a pharmacy through drug reserves.

While from the analysis of interviews with doctors Balimed Hospital stated that doctors are responsible for finding drugs when they run out or looking for a replacement. Help explain to patients the matter of drugs not available. Pay claims on time to the hospital. Procurement of drugs should be calculated with good amounts so that it does not occur until certain drug vacancies occur in a long time. The Social Security Administration Agency of Health should provide clear and appropriate socialization of the drugs that are covered and available, regarding the vacancy of the drug should be given a replacement option that is covered so that patients do not get therapy according to the needs of the disease. Medicines according to Formularium National are always available, especially emergency medicines or antibiotics so that they do not hamper medical services and do not harm patients because of the unavailability of drugs. Find an ideal drug / replacement. Finding a way out to keep providing medicine (not to empty) by collaborating with an outside pharmacy to provide medicine. The drug remains empty if the outside pharmacy does not have the drug.

Interview with Balimed Hospital Officials stated verification has been carried out but the drug often arrives late. Will be held and sent to patients directly with a maximum period of 7 days if the drug is available. By looking for suppliers directly, but not permitted by the Inspectorate if it does not fit into the E Catalog in terms of price or type. By taking a bank 
bailout provided by the Social Security Administration Agency of Health but the Bank's interest is not paid by the Social Security Administration Agency of Health. Try to find drugs by searching and buying directly from suppliers whose prices are much more expensive because of the small volume. Empty drugs because the Social Security Administration Agency of Health often changes its rules suddenly without being agreed with the hospital first. Seek to find medicine by searching and buying directly from suppliers. The compensation obtained is usually in the form of a substitute drug that may have the same reaction depending on the doctor. By finding a direct supplier by taking a bailout from the bank provided by finding a direct supplier if the drug is empty we are looking for a similar drug with a discount that matches the price of the Social Security Administration Agency. ForNas medicine is empty, for example Amytiphilin. There is often a vacancy for the drug from the distributor. If there is a vacancy: look for other drugs at a price equal to the Social Security Administration Agency of Health 's medicines, chronic outpatients are given 7 days medicine, then the drugs for 23 days are referred to a companion pharmacy. Contact the whether the drug is stopped or replaced with another drug. Reports are made in the Meso form and reported to E-MESO. By taking a bailout from the bank provided

Interview with Balimed Hospital Officials stated verification has been carried out but the drug often arrives late. Will be held and sent to patients directly with a maximum period of 7 days. By finding a direct supplier. By taking a bank bailout provided by the Social Security Administration Agency of Health but the Bank's interest is not paid by the Social Security Administration Agency of Health. Try to find drugs by searching and buying directly from suppliers whose prices are much more expensive because of the small volume. Empty drugs because the Social Security Administration Agency of Health often changes its rules suddenly without being agreed with the hospital first. Seek to find medicine by searching and buying directly from suppliers. Patients / participants of the Social Security Administration Agency of Health should be able to report to the Social Security Administration Agency of Health if complaints or problems are found related to differences in doctor's prescription and received drugs. The compensation obtained is usually in the form of a substitute drug that may have the same reaction depending on the doctor.

\section{Legal protection for patients Social Security Administration Agency of Health of the elderly who do not get curative therapy in hospitals according to the National Health Insurance Office}

One of the most important factors to see to what extent there is legal protection in a hospital is the fulfillment of the patient's rights. The provision of curative therapy to all participants of the Health Social Security Administration Agency of Health, including the elderly, follows the minister of health's regulation by providing curative therapy in the form of generic drugs. This is in accordance with the Indonesian Case Base Groups (INA-CBGs) Guidelines in the Implementation of National Health Insurance. There are two hospital payment methods used, namely retrospective payment methods and prospective payment methods. Retrospective payment methods are

The researcher examines the existing problems using the theory of legal certainty, the theory of justice and the theory of expediency. Related to legal certainty in this case the researcher will analyze how the process of drug emptiness occurs in patients, both at Sanglah Hospital and at Balimed Hospital in Denpasar is associated with the provisions of the Law on the Agency The relevant Health Social Security Provider, the Health Act, the Republic of Indonesia Law Article $28 \mathrm{H}$ and $3 \mathrm{c}$ consumer protection.

Legal protection for patients is deemed necessary to be regulated more deeply in laws relating to patients as consumers, so as to create a legal certainty regarding the legal protection of these patients. Curative therapy is a patient as a recipient of health services for elderly (Peraturan Menteri Kesehatan Republik Indonesia, 2016).

In this research, a study was conducted on the legal protection of patients participating in the Health Insurance Agency for the elderly as service consumers in health services, to see whether legal protection for patients as service consumers in health services already exists or can be implemented or not, researchers analyzed from the Law the law relating to patients as consumers of services in health services is to analyze the 
rights of patients, because to assess whether or not there is protection for patients, the priority is the fulfillment of the rights of the patient itself and the researcher analyzes by reviewing Law No. 8 of 1999 concerning Consumers, Law No. 36/2009 concerning Health, Law No. 29/2004 concerning Medical Practices and Law No. 44/2009 concerning Hospitals.

Legal protection is all efforts to fulfill rights and provide assistance to provide security for witnesses and / or victims, legal protection for victims of crime as part of community protection, can be realized in various forms, such as through the provision of restitution, compensation, medical services, and legal assistance.

The above understanding invites several experts to express their opinions regarding the understanding of legal protection including (Sidabalok, 2010):

1. According to Satjipto Raharjo, defining Legal Protection is to provide protection to the human rights desired by others and the protection is given to the community so that they can enjoy all the rights granted by law.

2. According to Philipus M. Hadjon argues that legal protection is the protection of dignity and dignity, and recognition of human rights owned by legal subjects based on the legal provisions of arbitrariness.

3. According to the CST Kansil Legal Protection is a variety of legal efforts that must be given by law enforcement officials to provide a sense of security, both mind and physical from interference and various threats from any party.

4. According to Philipus M. Hadjon, Legal Protection is a collection of rules or rules that will be able to protect one thing from another (Anonim, 2017).

The Responsibility of the Social Security Administration Agency of Health in Fulfilling its Obligations to Patients The Health Insurance Organizing Body of the Elderly in Curative Therapy in accordance with the national formulary of National Health Insurance

Of the twenty patients from Sanglah Hospital and Balimed Hospital in Denpasar still did not get a change of medication in accordance with the indications of the disease, whereas in the rules of the Minister of Health and through the INA CBG it was explained that the patient was entitled to get the drug according to the indication of the disease. Referring to the legal norms that are legal obscurity or referred to as blurring norms as well as these can be considered as achievements of the Health Insurance Agency, in general and the elderly in particular. The State, in this case the Government, should be responsible for the participants of the Social Insurance Provider by one of them repeating the MOU with the Health Insurance Administering Agency, improving matters related to curative therapy in elderly patients that have not been able to be carried out by the Guarantee Agency Social Health.

Legal responsibility has several meanings. According to Wahyu Sasongko, legal responsibility is the obligation to bear an effect according to applicable legal provisions and here there are norms or legal regulations governing liability. When there is an act that violates the legal norms, the culprit can be held accountable according to the legal norms that are violated (Suma, 2009; Tyokronisilicus, 2011).

The Social Security Organizing Body funds health has not yet come down or is late to hospitals in Indonesia and is requested at the hospital to try to borrow capital to finance its hospitals for patients of the Health Social Security Administration Agency of Health by appointing a bank that is a partner of the National Health Social Security Administering Board, which is currently happening the bank loan interest is the hospitals throughout Indonesia, causing the collapse of the hospital. The National Health Insurance Administering Body should pay the bank interest borrowed by the hospitals in Indonesia by repaying the bank interest as a form of full legal responsibility from the National Health Insurance Administering Body in the framework of its responsibility to make the insurance consumer protected in accordance with Law No. 8/1999 concerning consumer protection, that is the obligation of business actors, in this case the Health Social Security Administration Agency, to protect consumers. It is also recommended to the National Health Social Security Administering Board to be able to work together / make an MOU 
with the respective local governments in Indonesia through the Regional Budget so that they can help issue grants to the Regional Health Social Security Administering Body in terms of joint financing of health services in each region. Mainly in Bali which already has a Province of Bali Regulation No. 11 of 2018 concerning elderly welfare (Peraturan Daerah Provinsi Bali, 2018).

\section{CONCLUSION}

In principle, legal protection must refer to legal certainty, fairness and benefits for the population participating in the Health Insurance Organizing Agency for the elderly so that it is not impressed that Balimed Hospital and Sanglah Hospital and the Health Social Security Administration Agency of Health make a service to consumers who are not good.

The legal responsibility that should be obtained by the participants of the Social Security Administration Agency of Health of the elderly in Balimed Hospital and Sanglah Hospital Denpasar which is currently not maximally received by the patients participating in the elderly Social Security Organizing Board in Balimed Hospital and Sanglah Hospital by each hospital and Agency Organizers of the Bali Social Health Insurance so that the three institutions ignore legal responsibility and do not enforce the priority principle of patients participating in the Health Insurance Agency for the elderly.

\section{REFERENCES}

Anonim. (2017). Tanggung Jawab Hukum. Retrieved from SudutHukum website: https:// suduthukum.com/2017/02/tanggung-jawab-hukum.html

AntaraNews. (2016). Pasien BPJS Masih Disuruh Beli Sendiri Obat Dan Darah.

Danandhika, N. R., Putrawan, S., \& Bagiastra, I. N. (2016). Perlindungan Hukum bagi Peserta Tidak Mampu BPJS Kesehatan dalam Mengakses Jasa Pelayanan Kesehatan di RSU Puri Raharja (dalam Perspektif Perlindungan Konsumen). Kertha Semaya, 4(3). Retrieved from https:// ojs.unud.ac.id/index.php/kerthasemaya/article/view/37423

Denkin, N. K. (2013). Triangulasi dalam penelitian kualitatif. Retrieved November 25, 2019, from Hartatyfatshaf.blogspot.com

Ina CBGs. (2017). Drags for National Government Insurance.

Kemenkes-RI. (2014). Buku Pegangan Sosialisasi Jaminan Kesehatan Nasional dalam Sistem Jaminan Sosial Nasional. Jakarta: Kemenkes-RI.

Republika. (2018). Duh, pasien BPJS Kesehatan Masih Dibebani Biaya Obat. Retrieved from https:// www.respublika.id/2018/09/18/duh-pengguna-bpjs-kesehatan-masih-dibebani-biaya-obat/

Sidabalok, J. (2010). Hukum Perlindungan Konsumen di Indonesia. Bandung: Citra Aditya Bakti.

Siregar, E., \& Budhiartie, A. (2013). Perlindungan Hukum Hak-Hak Pasien Dalam Transaksi Terapeutik. Majalah Hukum Forum Akademika, 24, 172.

Suhartoyo. (2018). Perlindungan Hukum Bagi Pekerja Peserta BPJS Kesehatan di Rumah Sakit. Adminitrative Law \& Governance Journal, 1(2). Retrieved from http:/l download.garuda.ristekdikti.go.id/article.php?article=777674\&val=12745\&title=Perlindungan Hukum Bagi Pekerja Peserta BPJS Kesehatan di Rumah Sakit

Suma, J. (2009). Tanggung Jawab Hukum dan Etika Kesehatan. Jurnal Legalitas, 2(3). Retrieved from https://ejurnal.ung.ac.id/index.php/JL/article/view/665

Susamto, B. (2011). Pemikiran Hukum Perindungan Konsumen \& Sertifikasi Halal (UIN-MAIKI). Malang.

Tyokronisilicus. (2011). Pertanggungjawaban Hukum. Retrieved from https:// tyokronisilicus.wordpress.com/2011/11/04/teori-hans-kelsen-mengenai-pertanggungjawabanhukum/

Yudiana, I. G., Listyaningrum, N., \& Dwi, B. N. (2020). Perlindungan Hukum bagi Pasien Pengguna Badan Penyelenggaraan Jaminan Sosial (BPJS) di Rumah Sakit Kota Mataram. Media Bina IImiah, 14(12). Retrieved from https://ejurnal.binawakya.or.id/index.php/MBI/article/view/600

Undang-Undang No 8 Tahun 1999 tentang Perlindungan Konsumen (Lembaran Negara Republik Indonesia Tahun 1999 Nomor 42, Tambahan Lembaran Negara Republik Indonesia Nomor 3821)

Peraturan Menteri Kesehatan Republik Indonesia Nomor 512 Tahun 2007 tentang Izin Praktik dan Pelaksanaan Praktik Kedokteran

Peraturan BPJS Kesehatan. 2014. Peraturan BPJS Kesehatan Nomor 1 Tahun 2014 tentang 
Penyelenggaraan Jaminan Kesehatan (Berita Negara Republik Indonesia Tahun 2014 Nomor 1).

Peraturan Menteri Kesehatan Nomor 79 Tahun 2014 tentang Penyelenggaraan Pelayanan Kesehatan Geriatri Di RS (Berita Negara Republik Indonesia Tahun 2014 Nomor 1752)

Peraturan Menteri Kesehatan Republik Indonesia Nomor HK.02.02/MENKES/524/2015 tentang Pedoman Penyusunan dan Penerapan Formularium Nasional. Jakarta : Depkes RI

Peraturan Menteri Kesehatan Republik Indonesia Nomor 25 Tahun 2016 tentang Rencana Aksi Nasional Kesehatan Lanjut Usia Tahun 2016-2019.

Peraturan Menteri Kesehatan RI No. 76 Tahun 2016 tentang Pedoman Indonesia Case Base Groups (INA-CBG)

Peraturan Daerah Provinsi Bali Nomor 11 Tahun 2018 tentang Kesejahteraan Lanjut Usia. 